\title{
About the preservation of ancient art: Egypt
}

\begin{abstract}
Based on personal impressions gathered during my stay in Egypt in the beginning of 1998 , this article focuses on the preservation of art in ancient Egypt. It is particularly inspired by the long and unforgettable conversation I had then with Professor Raymond Johnson, Field Director of The Epigraphic Survey of Chicago House, in Luxor. The destruction of the ancient art produced in the cradle of civilization means not only a breach with the past; it is also a bad omen for the very existence of art in the future of mankind.
\end{abstract}

Keywords: Egypt, art, middle east, preservation, humanity
Volume 3 Issue $3-2018$

\section{João Vicente Ganzarolli de Oliveira}

Professor and Researcher of the Tércio Pacitti Institute of the Federal University of Rio de Janeiro, Brazil

Correspondence: João Vicente Ganzarolli de Oliveira, Professor and Researcher of the Tércio Pacitti Institute of the Federal University of Rio de Janeiro, Av. Pedro Calmon, 550, Cidade Universitária (RJ, 2194I-90I), Brazil, Tel +55 2I393896 00, Email jganzarolli@usa.com

Received: May 17, 2018 | Published: June 29, 2018

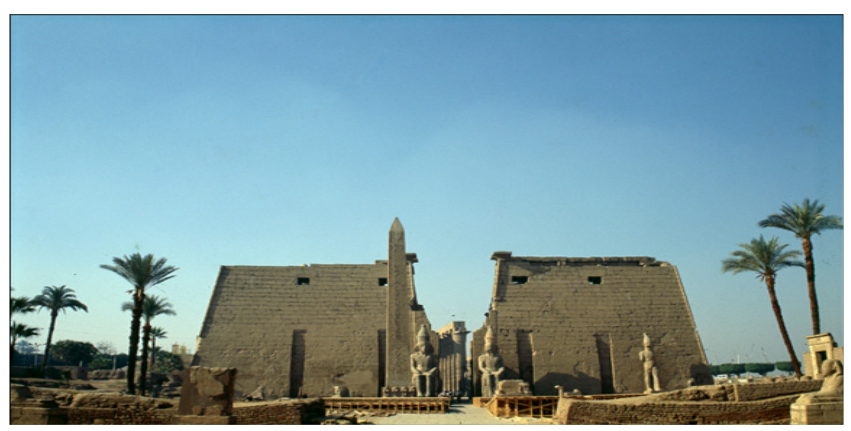

Karnak (Egypt, photo taken by the author).

What is the importance for us of this civilization, so long-lived and immortal in its material expressions?

John Albert Wilson

\section{Introduction}

"How much did you pay for it?", asked me a young man in Cairo, referring to the book I was holding in my hands. ${ }^{1}$ We were both in a bus which was going to the plain of Giza, and reading seemed to me a good way of taking profit of the slow traffic in the biggest city of the Middle East. If he wanted (as he did) to start a conversation aiming to convince me to ride a camel around the Pyramids, there would be at least two possibilities: he could have gone straight to point, or he could have beaten about the bush. Cairo, the first city I visited in Egypt, represented the last stage of my stay in the Middle East in 1998. I was and still am particularly interested in the preservation of ancient art. That is the reason why I put the stress on the attitude of the young man during my trip to the pyramids of Giza -one of the few survivals of the Seven Wonders of the Ancient World and the most well preserved of them. It was not an isolated fact, but one amongst many others of the same kind, since the beginning of my travel, started in Istanbul some months before. In giving priority to the price of the object, the young man expressed much more than his personal values; he expressed a mentality that dwells in the basis of the destruction of the works of art in Egypt and in the rest of the cradle of civilization. Destroying a work of art does not mean necessarily breaking it into pieces, as it occurred in Europe with catholic sculptures during the Reformation. Modern iconoclasts do not resort only to vandalism to achieve their target - let's consider the destruction of Palmyra's monuments, in Syrian Mesopotamia, by Muslim terrorists between 2015 and 2017; and the looting of some of the Egyptian Museum's treasures in 2011 by the occasion of the so-called "Arab Spring". Reducing works of art to mere tourist attractions can also be a very efficient mean to cause damage or even to destroy. As a matter of fact, predatory tourism can be worse than "traditional" ways of destruction, because it occurs in large scale - and many times on a subliminal, i.e., unconscious, level -, effacing the frontier between the territory of art and that of non-art. It all increasingly boils down to money and leisure: should I join an Egypt tour package, visit personally the Egyptian section of the Louvre or "enter" the one of the most mustsee museums of the world through internet access? To afford or not to afford, that has been the question.

\section{The Egyptian case}

Besides representing a patrimony of humanity in almost every area of culture, Egypt is also a privileged reference when it comes to the preservation of ancient art. Egyptian art was essentially devoted to eternity. Giving preference to the stone as a rough material, Egyptian sculptors and architects produced works that defied the inclemency of both nature and history. ${ }^{3}$ A similar procedure is followed in painting: rejecting illusory deepness, Egyptian painters aimed to free their figures from the vicissitudes of space and time: "Each figure aspire to eternal life thanks to its solidity and impassivity, avoiding every appearance of flexibility, of momentary action and of passing emotion". ${ }^{4}$ As Herodotus points out with accuracy, Egypt is "a gift of the Nile." Isolated by deserts, the fertile lands own to that river the geographical reason for their existence. Differently from the other great civilization that emerged at almost the same time less than one thousand miles Northeast between the Tigris and the Euphrates, Egypt, confined to this enormous oasis of the Nile valley, was much more protected against foreign influence. Such physical isolation prepared the field for an almost unbroken artistic continuity that lasted for millennia. The dry weather and the consequent shortage of rains certainly contributed to emphasize the importance of the Nile river, with its regular rise, as the responsible for the very possibility and thriving of live itself. In the words of William Stevenson Smith, "the 
regular rise of the Nile every year provided the striking example of a renewal of life with each annual flood and gave the Egyptian a cheerful assurance of the permanence of established things, suggesting the acceptance that life would somehow continue after death in the same way". ${ }^{6}$ According to him, "the peculiarly Egyptian concern with life after death in a form similar to that which had been experienced upon earth provided an element in the development of the arts which was not present to such an extend in another countries.

Thus, while architecture, painting, and sculpture ordinarily appeared in the service of the cult of a god to glorify the wealth and power of a ruler, in Egypt we find emphasis laid upon providing a lasting dwelling-place for the dead, the re-creation of life. ${ }^{7}$ Magically in pictures to serve him, and lastly the provision of a substitute in stone for his perishable body". Such phenomena become even more noteworthy when one establishes a comparison between Egypt and Greece. Surrounded by the sea, the Greek man saw in the water not a sign of the repetition of things, as the Egyptians; water, thanks to its ability of being in constant movement and of existing in the three physical states (solid, liquid, gas), was much more regarded as a symbol of the transformations to which the whole physical reality is submitted. According to the pre-Socratic philosopher Heraclitus, "No man ever steps in the same river twice, for it's not the same river and he's not the same man". ${ }^{8}$ It should be reminded that Thales from Miletus, the Greek-Phoenician pre-Socratic philosopher who considered the water as the principle (arché) of all physical beings, created a theory to explain the regularity of the Nile's rises. ${ }^{9}$ Herodotus' Egypt and Egyptians seem to be as old as the world itself. Actually, "a very ancient kingdom, by about 3000 B.C. Egypt had developed one of the early civilizations of the ancient world". ${ }^{10}$ As a matter of fact, the very Egyptian landscape suggests an immutability that is reflected in social order and even in daily life without forgetting that the landscape has a history of its own, as "an organizing and analytical concept within the cultural geography", and that the influence between natural environment and culture works in both ways: landscape contributes to the formation of the mentality of a society, whose members modify the natural space that surrounds them. Little wonder that Egyptian ancient society was based on "the triumphant daily reborn of the sun and the victorious annual reborn of the river; from both miracles the Egyptians deduced the certainty that Egypt was the centre of the universe and that the renewed life always overcomes death". ${ }^{12}$

Egyptian artists did not have the inclination towards fearsome figures typical of the art produced by their neighbors of Mesopotamia and Crete. As we have already mentioned, Egyptian art expresses the perpetuity that people observed in the peculiar ambience they were inserted in, distant from "a good many of the more frightening caprices of nature". ${ }^{13}$ In fact, "The availability of working materials is an influent factor which must be taken into consideration. The abundance of good stone was an advantage the Egyptian had over his contemporaries in the Southern Mesopotamia, who were forced to import their stone. The shape and small size of the slabs and boulders available to the Summerian conditioned the rounded forms and somewhat uneven quality of the sculptures. The Egyptian early learned how to cut blocks for building-stone ends, and the sculptor had at his disposal an enormous supply of rectangular blocks from the quarry. This might have been a practical reason for his predispositions towards cubical forms, in contrast to the rounded, conical shapes preferred by the Mesopotamian. It certainly contributed for the largeness of scale which is another outstanding feature of Egyptian work both in sculpture and architecture". ${ }^{14}$

\section{A question that remains}

As the North-American Archaeologist Raymond Johnson told me, during my visit to Luxor and Karnak twenty years ago, "In the last eighty years the destructive forces recognized long ago by the Egyptologist James Henry Breasted have increased dramatically. Today monuments are vanishing before they have been adequately studied. The building of the High Dam at Aswan, the rising ground water throughout the Nile valley, the demands of an exploding population and the expanding tourist industry have placed Egypt's Pharaonic remains in great danger. The ancient Egyptian heritage must be documented as completely and accurately as possible, before the ancient record is forever lost". ${ }^{15}$ True art and true beauty are as rare and fragile (as regards Egypt, climbing the ancient monuments and even touching them cause damage, since it adulterates the original colour of the surface); their rareness is a reason for our attributing value to them, and their fragility is a reason for our sparing no efforts to preserve them. The destruction of the ancient art produced in the cradle of civilization means not only a breach with the past; it is also a bad omen for the very existence of art in the future of mankind. A question remains: could we live without producing and contemplating works of art?.

\section{Acknowledgements}

I would like to express my acknowledgements to Professors Raymond Johnson and Helen Pearlstean, from Chicago House, and to Professor Mouhamed Nasr, from the Centre of Antiquities of Luxor, for their support during my stay in Egypt. I am also indebted to Professors Letícia Galluzzi, Tamara Quírico and Gustavo Schnoor (in memoriam), for the review of the text.

\section{Conflict of interest}

The author declares there is no conflict of interest.

\section{References}

1. It was the book I bought in Byblos on my way to Egypt: John Spencer Trimingham's. Christianity among the Arabs in Pre- Islamic Times (Beirut, Librairie du Liban, 1990), an excellent one by the way.

2. See Maclean, Ruth. Desecrated but still majestic: inside Palmyra after second Isis occupation, in https://www.theguardian.com/world/2017/ mar/09/inside- palmyra- syria - after- second - isis- islamic- stateoccupation; and Yolande Knell. "Egyptian Museum: Cairo's looted treasure", in https://youtu.be/tvEvgbFZDuc (2011/feb/13).

3. Gombrich, Ernst. A história da arte. In: Álvaro Cabral, editor. Rio de Janeiro, Zahar, 1985. p. 33.

4. Wilson, John. La cultura egipcia. In: Florentino M Torner, editor. México, Fondo de Cultura Económico, 1992. p. 88.

5. Herodotus. The Histories; II, 5.

6. Stevenson Smith, William. The Art and Architecture of Ancient Egypt (revised with additions by William Kelly Simpson), 3rd edition, London: Yale University Press; 1981. p. 15.

7. Ibid. 
8. Quoted by Seneca in Epistulae; VI, 58, 23.

9. See Aristotle. Metaphysics; I, 3.

10. Stevenson, Arthur J. et al. Webster's New Geographical Dictionary, Springfield/Massachusetts, Merriam Webster, 1988; p. 360.

11. Cosgrove, Denis et al. Handbook of Cultural Geography, London/ Thousand Oaks/New Delhi, SAGE, 2003; pp. 249-258.

12. Wilson, John. El pensamiento prefilosófico. In: Eli de Gortari, editor. Egipto y Mesopotamia (Spanish). 7th edition, Ciudad de México, Fondo de Cultura Económica, 1993. p. 54.
13. Stevenson Smith, William. The Art and Architecture of Ancient Egypt, op. cit.; p. 1

14. Id., p. 14.

15. Ganzarolli de Oliveira, João Vicente. Interviews, 1998. 